\title{
Analysis and finding the correlation of air quality parameters on the spread and deceased case of COVID-19 patients in India
}

\section{Bibek Saha}

National Institute of Technology Agartala

Animesh Debnath ( $\nabla$ debnathanimesh@gmail.com )

National Institute of Technology Agartala

Biswajit Saha ( $\sim$ biswajit.physics@gmail.com )

National Institute of Technology Agartala

\section{Short Report}

Keywords: Covid-19 pandemic, air quality, PM 2.5, correlation, India

Posted Date: June 12th, 2020

DOI: https://doi.org/10.21203/rs.3.rs-34647/v1

License: (c) (i) This work is licensed under a Creative Commons Attribution 4.0 International License.

Read Full License 


\section{Abstract}

Recent covid-19 pandemic state across the globe has brought some issues to be considered obviously for better sustainability of human society and economy. In this article a comprehensive study based on the air quality parameters has been represented in view the recent covid-19 situation in India. India being the second largest populated country in the world and having a very high population density is a vital region for controlling and observing the spread and recovery of covid-19 patients. It has been observed that the spread as well as recovery rate in India is far better than many other countries in the world. A noteworthy observation has been extracted in this study from the correlation between three Covid-19 parameters (total confirmed, active and deceased cases) and air quality index comprising of six air quality

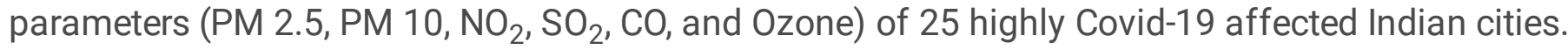
Spearman rank correlation and Kendall correlation tests were used to understand the correlation between the Covid-19 variables with air quality variables. Both the statistical correlation test revealed that particulate matters like PM 2.5, PM 10, and overall air quality have significantly strong correlation with the Covid-19 spread and death cases in 25 cities of India. However, the PM 2.5 is found to be the most significant air quality parameter for Covid-19 spread and death cases in India. It indicates that the western part of India contains more risk zones as compared to the north-eastern and eastern part of the country. The high natural vegetation, less industrial areas of the northeast India with better air quality finds higher recovery rate. Similarly the high natural vegetation of the Himalayan zones are also comparatively having better air quality and experiencing better control of covid-19 cases.

\section{Introduction}

The entire world is recently passing through a very critical pandemic situation. Within four months as on April 2020, the world has lost more than 230,000 people and about $3,250,000$ people affected. The figures are still increasingacross the globe. Many countries are severely affected. It has therefore become necessary to extract out and obtain the information of all relevant parameters like atmospheric pollution (Fattorini et al., 2020; Conticini et al., 2020), travel (Chinazzi et al., 2020), air quality(Yongjian et al., 2020), etc to maintain the situation under control until a vaccine ormedicine comes in hand to control it.Numbers of such reports are coming up from different regions of the world (Maier and Brockmann, 2020; Bashir et al., 2020; Tosepuet al.,2020;). The population density and the total population in India are very large. It is the second highest populated country in the world with 1.36 billion of people and 455people per $\mathrm{Km}^{2}$ average population density(World Bank Data). However the health infrastructures in the country are not up to the mark as compared with different developed countries in the world. So it is of extreme need of analyzing the situation in this country for the protection of a significant number of people of the world. It is very important to mention that, as compared with other countries the situations in India is far better and much under control. Thus it creates a space for studies to analyze and find the factors appeared in favor of better control, and obtaining the correlation of those factors. This has therefore become necessary to obtain the knowledge of significant factors, that would becomeuseful for 
the human society considering the future of the coming days in world, and to manage its economic state towards a better direction.

In the present time the spread, recovery and mortality rate of Covid-19 patients can be assumed to be broadly dependent onfour factors like (a) societal and human behavioral factor(b) treatment and health infrastructure. (c) local environmental factors and (d) individuals health immunity power. Out of these four factors the first factor controls the spread of the virus in the society. The other factors are mainly related with the recovery and mortality rates. The second factor in India is not too satisfactory. Still India is in a comparatively better position indicates somewhat related with long term environmental effects over the individuals health and immunity power. Being inspired with this we have undertaken an objective to obtain a correlation of environmental parameters with the spread of the covid-19 cases within India.

According to the report of the World Health Organization (WHO), around 4.2 million deaths per year occur due to air pollution and more than $90 \%$ of the world's population lives in areas where the air quality is unsafe. In the study conducted by IQAir, AirVisual and Greenpeace, India is found to have seven of the worst 10 cities having the worst air quality in the world. Prolonged exposure to unhealthy air causes various lung ailments that explicitly spell danger in human beings. As severe respiratory problems are known to be related with air quality of individuals living site (Sharma et al., 2020; Chen et al., 2019;Croft et al., 2019; Conticini et al., 2020), we have studied the case with the air quality of different locations in India. Investigation on prolonged exposure of air quality and its effect on covid-19 pandemic are still very inadequate. A recent study reported that the air quality have significant correlation with COVID-19 pandemic (Bashir et al., 2020). It was reported that air quality of New York City of USA is highly correlated with total cases, new cases and mortality of Covid-19. However, the details of correlation between important air quality parameters with COVID-19 pandemic not yet explored properly.

Hence, in this study, the correlation between Covid-19 spread, death cases and air quality index

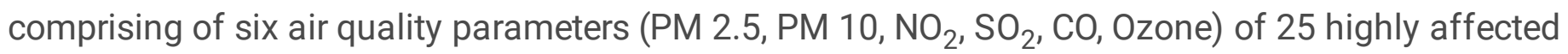
Indian cities have been analyzed and the most significant air quality parameters linked with Covid-19 were also evaluated. This study indicates that there is a significant correlation between the spread and recovery of Covid-19 patients with the air quality parameters.

\section{Methodology Of Study}

This objective of the study is mostlyto find the correlation between the air quality and Covid-19 pandemic in India. Therefore the methodology of this study is established on air quality and Covid-19 data collection and analysis, and it is detailed in the following sections.

\subsection{Selection of region of study}

This study has been conducted on different areas of India. The population distribution in India has a wide spectrum. As the spread of virus is highly related with the density of population and socioeconomic 
activities, it is rational to focus on the cities of the country with comparatively high population density. Twenty five different cities located at various parts of the country have been identified and selected for this study. The Fig.1 shows the places of population density distribution in India (Census report of Government of India).

\subsection{Data sources and collection scheme}

Data has been collected from two different types of sources, first one is the data source related to the spread of Covid-19, and mortality, and the other is the data source of air quality index at different affected areas. The Covid-19 data of different places of India were collected from the website of Ministry of Health and Family welfare, Government of India (Ministry of Health and Family welfare, Government of India). The period of data collection was from $30^{\text {th }}$ January 2020 to $5^{\text {th }}$ May 2020. Among 28 states of India, several cities of the states like Maharashtra, Gujarat, Delhi, Rajasthan, Madhya Pradesh, Tamil Nadu, Uttar Pradesh, Telengana, West Bengal, Karnataka, and Punjub are designated as hotspot for Covid-19 in India. Based on the above, 25 major cities, which are also hotspot of Covid-19 have been considered in this study. The list of 25 considered cities along with their Covid-19 patient details are mentioned in Table 1. Covid-19 data which have been included in this research are total confirmed, active, and deceased cases for each city as on $5^{\text {th }}$ May 2020. The 25 number cities were selected based on two criteria, (i) cities with high infection rate of Covid-19 cases, and (ii) availability of sufficient air quality index (AQI) data for those cities.

Table 1: List of the considered Indian cities with their Covid-19 patient details as on $5^{\text {th }}$ May 2020 


\begin{tabular}{|c|c|c|c|c|}
\hline $\begin{array}{l}\text { Location } \\
\text { code }\end{array}$ & City/District & $\begin{array}{l}\text { State/Union } \\
\text { Territory }\end{array}$ & $\begin{array}{l}\text { Covid- } 19 \text { cases in } \\
\text { the city/district }\end{array}$ & $\begin{array}{l}\text { Proportion of Covid-19 cases of } \\
\text { the city from state (\%) }\end{array}$ \\
\hline L1 & Mumbai & \multirow[t]{4}{*}{ Maharashtra } & 9,945 & 64 \\
\hline L2 & Pune & & 2,062 & 13 \\
\hline L3 & Nashik & & 409 & 3 \\
\hline L4 & Nagpur & & 181 & 1 \\
\hline L5 & Ahmadabad & \multirow[t]{2}{*}{ Gujarat } & 4,425 & 71 \\
\hline L6 & Surat & & 723 & 12 \\
\hline L7 & Delhi & Delhi & 5,104 & 100 \\
\hline L8 & Jaipur & \multirow[t]{3}{*}{ Rajasthan } & 1047 & 33 \\
\hline L9 & Jodhpur & & 762 & 24 \\
\hline L10 & Kota & & 221 & 7 \\
\hline L11 & Indore & \multirow{3}{*}{$\begin{array}{l}\text { Madhya } \\
\text { Pradesh }\end{array}$} & 1,654 & 54 \\
\hline L12 & Bhopal & & 571 & 19 \\
\hline L13 & Ujjain & & 184 & 6 \\
\hline L14 & Chennai & \multirow[t]{2}{*}{ Tamil Nadu } & 2007 & 49 \\
\hline L15 & Coimbatore & & 146 & 4 \\
\hline L16 & Agra & \multirow{2}{*}{$\begin{array}{l}\text { Uttar } \\
\text { Pradesh }\end{array}$} & 640 & 22 \\
\hline L17 & Kanpur & & 276 & 10 \\
\hline L18 & Hyderabad & Telengana & 591 & 54 \\
\hline L19 & Kolkata & \multirow[t]{2}{*}{ West Bengal } & 700 & 52 \\
\hline L20 & Howrah & & 265 & 20 \\
\hline L21 & Bengaluru & \multirow[t]{2}{*}{ Karnataka } & 153 & 23 \\
\hline L22 & Mysuru & & 88 & 13 \\
\hline L23 & Jalandhar & \multirow[t]{3}{*}{ Punjub } & 134 & 9 \\
\hline L24 & Amritsar & & 218 & 15 \\
\hline L25 & Ludhiana & & 124 & 9 \\
\hline
\end{tabular}

The air quality index (AQI)data of the considered cities were collected from the web portal of the Central Pollution Control Board (CPCB), Ministry of Environment, Forest and climate change,Govt. of India 
(Central Pollution Control Board). The National AQI considers eight key air pollutants, including particulate matters (PM 2.5, PM 10), sulphur dioxide $\left(\mathrm{SO}_{2}\right)$, nitrogen dioxide $\left(\mathrm{NO}_{2}\right)$, carbon monoxide (CO), ozone $\left(\mathrm{O}_{3}\right)$, ammonia $\left(\mathrm{NH}_{3}\right)$ and lead $(\mathrm{Pb})$. The details of category range of air pollutants as per National air quality index of CPCB are tabulated in Table 2. This is clear from the table that higher the pollutant AQI value, poorer is the air quality. Based on the concentration of any particular air pollutant, subsequent standards and possible health problems, a sub-index is determined for each of these air pollutants. Subsequently the most awful sub-index indicates the overall AQI. Detailed methodology for calculation of pollutant AQI and overall AQI under the National Air Quality Index (IND-AIQ) can be obtained from the report of National Air Quality Index, Control of urban pollution series, CUPS/82/2014-15.

Table 2: Category range of AQI as per National Air Quality Index, CPCB (2014)

\begin{tabular}{|lllllllll|}
\hline $\begin{array}{l}\text { AQI Category } \\
\text { Range }\end{array}$ & $\mathrm{PM}$ & $\mathrm{PM} 10$ & $\mathrm{SO}_{2}$ & $\mathrm{NO}_{2}$ & $\mathrm{CO}$ & $\mathrm{O}_{3}$ & $\mathrm{NH}_{3}$ & $\mathrm{~Pb}$ \\
\hline Good & 2.5 & & & & & & & \\
\hline Satisfactory & $51-50$ & $0-30$ & $0-40$ & $0-40$ & $0-1.0$ & $1-50$ & $0-200$ & $0-0.5$ \\
\hline $\begin{array}{l}\text { Moderately } \\
\text { Polluted }\end{array}$ & $101-$ & $61-90$ & $41-80$ & $41-80$ & $\begin{array}{l}1.1- \\
2.0\end{array}$ & $51-100$ & $201-400$ & $0.5-$ \\
Poor & 250 & & & & & & 1.0 \\
& $251-$ & $91-120$ & $381-$ & $181-$ & $10-17$ & $169-$ & $801-$ & $2.1-$ \\
Very Poor & 350 & & 800 & 280 & & 208 & 1200 & 3.0 \\
\hline Severe & $351-$ & $121-$ & $801-$ & $281-$ & $17-34$ & $209-$ & $1200-$ & $3.1-$ \\
\hline
\end{tabular}

\subsection{Data analysis Method}

In this study, the collected Covid-19 data as well as the AQI data for the 25 considered cities are not normally distributed. Hence the Spearman rank correlation and Kendall correlation testswere used to understand the correlation between the Covid-19 variables with AQI variables. The correlation between three Covid-19 variables (total confirmed, active, and deceased cases) were determined with seven AQI variables (PM 2.5 AQI, PM 10 AQI,NO ${ }_{2}$ AQI, $\mathrm{SO}_{2}$ AQI, CO AQI, Ozone AQI, and overall AQI).

\section{Results And Discussions}

\subsection{Analysis of theCovid-19 datain the affected areas}


The spread of Covid-19 virusacross the globe has undergone a rapid increase. In India this virus affected people have been found at almost all regions of the country. But the spread and increase of cases are not uniform at all places. The government is keeping regular district wise update of virus affected cases across the country. After suffering over month lockdown condition it has become a challenge to the government to manage the economic status of the country of 1.36 billion people. On that ground, government has taken a nice step to divide the county at district level into three different zones. There are red zones, orange zones and green zones imposed with the restrictions of three different ranks in three different zones respectively during the extended lockdown period. This obviously created a nice distribution map of Covid-19 cases across the country as illustrated in the Fig. 2.

Fig. 3 depicts the details of total confirmed, active, recovered and deceased Covid-19 cases of India as on $5^{\text {th }}$ May 2020. It can be observed that first case of Covid-19 was reported in India on $30^{\text {th }}$ January 2020 , however the rapid growth in Covid-19 cases was started in the last week of March and as on $5^{\text {th }}$ May the total cases reached at 49,405 . Out of which total active cases were 33571, recovered cases of 14140 and deceases cases of 1694 . Thus the trend of Covid-19 pandemic in India is nearly $68 \%$ of active cases, and $27 \%$ of recovery rate with only $3.4 \%$ of fatality rate, which is much lower than many other countries.

\subsection{Analysis of air quality index data}

There have been some early suggestions that the spread and recovery of Covid-19 may vary with the change of seasons. Primarily it was also appeared to seem that the outbreaks of the new disease due to Covid-19 virus at different parts of the globe has an inclination for cool and dry conditions, though it is worth noting that the cases are found to spread severely in countries with a wide range of climates, including hot humid ones(Qi et al., 2020). Thus we approached to study the present situation of Covid-19 with the air quality in different places of India. The long-term exposure to the polluted air is dangerous for public health (Shaddick et al., 2018; Rovira et al., 2020). Particularly the diseases related with respiratory problems are more likely to be severe for the people living for decades in a region of fine particulate in air(Frontera et al., 2020; de Souza et al., 2018).As a result of fast economic growth and rising fossil fuel use, air pollution is now a major public health issue in the Asia-Pacific region.Therefore the air quality parameters are considered for analysis to find a correlation with total confirmed, activeand deceased Covid-19 casesin different parts of India. In the AQI data, six air pollutants were considered namely PM 2.5, PM10, $\mathrm{NO}_{2}, \mathrm{SO}_{2}, \mathrm{CO}$, and Ozone. Although the National air quality index of CPCB consider eight pollutants, including particulate matter (PM 2.5, PM 10), sulphur dioxide $\left(\mathrm{SO}_{2}\right)$, nitrogen dioxide $\left(\mathrm{NO}_{2}\right)$, carbon monoxide $(\mathrm{CO})$, ozone $\left(\mathrm{O}_{3}\right)$, ammonia $\left(\mathrm{NH}_{3}\right)$ and lead $(\mathrm{Pb})$. But, the parameters ammonia $\left(\mathrm{NH}_{3}\right)$ and lead $(\mathrm{Pb})$ have not included in this study on account of insufficient data in the target cities. The air quality data of six important parameters have been collected for the month of December 2019. In cities with multiple monitoring stations, the arithmetic mean value of air quality parameters of all monitoring stations has been considered. 


\subsection{Correlation between air quality and Covid-19 cases}

On observing and comparing the Fig. 1 and Fig. 2 one can easily realize that the spread of Covid-19 is not only and significantly associated with the population density in India. That is also a reason, which has driven us to consider the matter of prevailing air quality with Covid-19 spread in different places of India. Initially the Spearman and Kendallcorrelation coefficients between total covid-19 cases with seven AQI values for 25 cities are determined. The obtained coefficientvalues and the significance of each correlation coefficient value (with 95\% confidence level and two tail test) are shown in Table 3. As per Spearman correlation test, the total Covid-19 cases are significantly correlated with pollutant AQI like PM 2.5, PM 10, $\mathrm{SO}_{2}$, and overall AQI. Out of them, PM 2.5 AQI has shown highest and most significant correlation $\left(r_{s}=0.698 ; P\right.$ value $\left.<0.001\right)$ followed by overall AQI $\left(r_{s}=0.693 ; P\right.$ value $\left.<0.001\right)$. However, the air quality parameters like $\mathrm{NO}_{2}, \mathrm{CO}$ and Ozone do not have any significant correlation with $\mathrm{P}$ value more than 0.005. The Kendall correlation test results also support the spearman correlation results. Similar to Spearman test, Kendall correlation test also indicates PM 2.5 AQI as the most influencing parameter $(\mathrm{w}=$ $0.850 ; P=0.018$ ) in total Covid-19 confirmed cases in India. The location wise variation between total confirmed Covid-19 cases and PM 2.5 AQI is depicted in Fig. 4. Sufficiently good agreement between total confirmed Covid-19 cases and PM 2.5 AQI can be observed in most of the considered location, resulting to highest correlation between them.

Table 3: The Spearman and Kendall correlation coefficients between air quality index variables with Total Covid-19 confirmed cases in different cities of India 


\begin{tabular}{|c|c|c|c|c|}
\hline & $\begin{array}{l}\mathrm{AQI} \\
\text { variables }\end{array}$ & $\begin{array}{l}\text { Total Covid-19 confirmed } \\
\text { cases }\end{array}$ & $\begin{array}{l}P \\
\text { value }\end{array}$ & Remarks \\
\hline \multirow{7}{*}{$\begin{array}{l}\text { Spearman correlation } \\
\text { coefficient }\left(r_{s}\right)\end{array}$} & PM 2.5 AQI & 0.698 & $<0.001$ & \multirow[t]{2}{*}{ Significant } \\
\hline & PM 10 AQI & 0.567 & 0.004 & \\
\hline & $\mathrm{NO}_{2} \mathrm{AQI}$ & 0.359 & 0.078 & Insignificant \\
\hline & $\mathrm{SO}_{2} \mathrm{AQI}$ & 0.500 & 0.001 & Significant \\
\hline & CO AQI & 0.381 & 0.061 & \multirow[t]{2}{*}{ Insignificant } \\
\hline & Ozone AQI & 0.021 & 0.923 & \\
\hline & Overall AQI & 0.693 & $<0.001$ & Significant \\
\hline \multirow{7}{*}{$\begin{array}{l}\text { Kendall correlation coefficient } \\
\text { (w) }\end{array}$} & PM 2.5 AQI & 0.850 & 0.018 & \multirow[t]{2}{*}{ Significant } \\
\hline & PM 10 AQI & 0.786 & 0.037 & \\
\hline & $\mathrm{NO}_{2} \mathrm{AQI}$ & 0.679 & 0.113 & Insignificant \\
\hline & $\mathrm{SO}_{2} \mathrm{AQI}$ & 0.767 & 0.046 & Significant \\
\hline & CO AQI & 0.683 & 0.109 & \multirow[t]{2}{*}{ Insignificant } \\
\hline & Ozone AQI & 0.516 & 0.420 & \\
\hline & Overall AQI & 0.845 & 0.019 & Significant \\
\hline
\end{tabular}

Secondly the Spearman and Kendall correlation tests between active Covid-19 cases with seven AQI values of 25 locations are calculated, and correlation coefficients with their significance status are shown in Table 4. It is quite clear from both Spearman and Kendall correlation tests that active Covid-19 cases of 25 cities are also significantly correlated with air quality parameters like PM 2.5, PM 10, $\mathrm{SO}_{2}$, and overall AQI. That means active Covid-19 cases correlation coefficients are showing similar trends with the total confirmed Covid-19 cases. However the active Covid-19 case correlation coefficients are slightly lesser than the total confirmed Covid-19 cases. Here also, PM 2.5 AQI is found to be the most significant parameter affecting the active Covid-19 cases in both Spearman test $\left(r_{s}=0.692 ; P\right.$ value $<0.001)$ and Kendall test $(w=0.847 ; P$ value $=0.018)$. PM 10 is found to be as the second most important parameter affecting the active Covid -19 casesby both Spearman $\left(r_{s}=0.531 ; \mathrm{P}\right.$ value $=$ $0.006)$ and Kendall test $(w=0.768 ; P$ value $=0.045)$. Thus it is clear that the particulate mattes have major impact on Covid-19 pandemic, and smaller the particle size higher is the risk factor. Primary gaseous air pollutants like $\mathrm{NO}_{2}, \mathrm{CO}$ and secondary air pollutants like Ozone do not have any significant impact on the spread of Covid-19 cases. The graphical representation of this close agreement between active Covid-19 cases and PM 2.5 AQI for 25 locations of India is shown in Fig. 5. Thus the importance of PM 2.5 in Covid-19 spread in India is clearly established. 
Table 4: The Spearman and Kendall correlation coefficients between air quality index variables with active Covid-19 cases in different cities of India

\begin{tabular}{|c|c|c|c|c|}
\hline & $\begin{array}{l}\mathrm{AQI} \\
\text { variables }\end{array}$ & $\begin{array}{l}\text { Active Covid-19 } \\
\text { cases }\end{array}$ & $\begin{array}{l}P \\
\text { value }\end{array}$ & Remarks \\
\hline \multirow{7}{*}{$\begin{array}{l}\text { Spearman correlation coefficient } \\
\left(r_{s}\right)\end{array}$} & PM 2.5 AQI & 0.692 & $<0.001$ & \multirow[t]{2}{*}{ Significant } \\
\hline & PM 10 AQI & 0.531 & 0.006 & \\
\hline & $\mathrm{NO}_{2} \mathrm{AQI}$ & 0.294 & 0.152 & Insignificant \\
\hline & $\mathrm{SO}_{2} \mathrm{AQI}$ & 0.502 & 0.010 & Significant \\
\hline & CO AQI & 0.329 & 0.108 & \multirow[t]{2}{*}{ Insignificant } \\
\hline & Ozone AQI & -0.083 & 0.693 & \\
\hline & Overall AQI & 0.684 & $<0.001$ & Significant \\
\hline \multirow[t]{7}{*}{ Kendall correlation coefficient (w) } & PM $2.5 \mathrm{AQI}$ & 0.847 & 0.018 & \multirow[t]{2}{*}{ Significant } \\
\hline & PM 10 AQI & 0.768 & 0.045 & \\
\hline & $\mathrm{NO}_{2} \mathrm{AQI}$ & 0.647 & 0.647 & \multirow[t]{4}{*}{ Insignificant } \\
\hline & $\mathrm{SO}_{2} \mathrm{AQI}$ & 0.768 & 0.768 & \\
\hline & CO AQI & 0.656 & 0.140 & \\
\hline & Ozone AQI & 0.463 & 0.565 & \\
\hline & Overall AQI & 0.840 & 0.020 & Significant \\
\hline
\end{tabular}

It is well known that, long-term-exposure to high levels of PM2.5 is associated positively with deaths related to respiratory system. As in case of Covid-19, respiratory problems are considered to be key symptoms, hence there may be a relation between the Covid-19 death cases with the prevailing air quality of any particular area. Hence, the Spearman and Kendall correlations tests were performed between Covid-19 death cases with seven AQI values. Results shown in Table 5 clearly indicate strong correlation between particulate matters with the Covid-19 death cases. PM $2.5 \mathrm{AQI}$ is found to be the most significant air quality parameter related to Covid-19 death cases(Spearman $r_{s}=0.654$ and $P$ value $<0.001$; Kendall $w=0.832$, P value $=0.022$ ) followed by PM 10. It means the places in India with higher PM 2.5 concentration in air are experiencing higher deceased cases due to Covid-19 pandemic. The significant correlation between Covid-19 death cases and PM 2.5 AQI can also be observed from the Fig. 6 for most of the considered cities in India. 
Hence it can be concluded that PM 2.5 is the most critical air quality parameter affecting Covid-19 spread (total confirmed and actives cases) as well as deceased cases in different locations of India as depicted in Fig. 7. Similar results were also reported by few recent studies in USA (Wu et al., 2020; Bashir et al., 2020). Wu et al., 2020 has examined the association between long-term exposure to polluted air and COVID-19 deaths, they found a strong association between elevated PM2.5 and increased COVID19 death rates. Probably long time exposure to PM 2.5 can reduce the people's ability to fight against infectious diseases like COVID-19, resulting to higher death cases. Moreover, small size particulate matters can act as a carrier for Covid-19 virus, and resulting to higher spread of Covid-19 in the areas with higher PM 2.5 concentrations in the air.

Table 5: The Spearman and Kendall correlation coefficients between air quality index variables with deceased Covid-19 cases in different cities of India

\begin{tabular}{|c|c|c|c|c|}
\hline & $\begin{array}{l}\mathrm{AQI} \\
\text { variables }\end{array}$ & $\begin{array}{l}\text { Deceased Covid-19 } \\
\text { cases }\end{array}$ & $\begin{array}{l}P \\
\text { value }\end{array}$ & Remarks \\
\hline \multirow{7}{*}{$\begin{array}{l}\text { Spearman correlation coefficient } \\
\left(r_{s}\right)\end{array}$} & PM 2.5 AQI & 0.654 & $<0.001$ & \multirow[t]{2}{*}{ Significant } \\
\hline & PM 10 AQI & 0.610 & 0.001 & \\
\hline & $\mathrm{NO}_{2} \mathrm{AQI}$ & 0.367 & 0.071 & Insignificant \\
\hline & $\mathrm{SO}_{2} \mathrm{AQI}$ & 0.514 & 0.009 & \multirow[t]{2}{*}{ Significant } \\
\hline & $\mathrm{CO} A \mathrm{Al}$ & 0.435 & 0.030 & \\
\hline & Ozone AQI & 0.203 & 0.331 & Insignificant \\
\hline & Overall AQI & 0.657 & $<0.001$ & Significant \\
\hline \multirow{7}{*}{$\begin{array}{l}\text { Kendall correlation coefficient } \\
\text { (w) }\end{array}$} & PM 2.5 AQI & 0.832 & 0.022 & \multirow[t]{2}{*}{ Significant } \\
\hline & PM 10 AQI & 0.811 & 0.028 & \\
\hline & $\mathrm{NO}_{2} \mathrm{AQI}$ & 0.687 & 0.105 & Insignificant \\
\hline & $\mathrm{SO}_{2} \mathrm{AQI}$ & 0.778 & 0.040 & Significant \\
\hline & CO AQI & 0.713 & 0.081 & \multirow[t]{2}{*}{ Insignificant } \\
\hline & Ozone AQI & 0.611 & 0.208 & \\
\hline & Overall AQI & 0.832 & 0.022 & Significant \\
\hline
\end{tabular}

Although results of this study reveal the strong correlation between prevailing PM 2.5 with the Covid-19 spread and deceased cases in Indian cities. However, it is too worth to mention that in addition to air quality, other weather/climatic parameters may play significant roles. Moreover, the societal and human 
behavioral factors, treatment and health infrastructure, and individual's health immunity power are the other factors to be considered for a comprehensive analysis.

\section{Conclusion}

In this research an effort was made to analyze the correlation between air quality and Covid-19 spread and deceased cases in different places of India using Spearman and Kendall test. Both the statistical correlation test revealed that air quality parameters like PM 2.5, PM 10, and overall AQI have correlation with the Covid-19 spread and death cases in 25 cities of India. However, the PM 2.5 is found to be the most significant air quality parameter for Covid-19 spread and death cases. The correlation coefficients between the PM 2.5 AQI and the active Covid-19 cases were found to be very high by both Spearman test $\left(r_{s}=0.692 ; P\right.$ value $\left.<0.001\right)$ and Kendall test $(w=0.847 ; P$ value $=0.018) . P M 10$ is found to be as the second most important parameter affecting the active Covid-19 cases by both Spearman $\left(r_{s}=0.531 ; P\right.$ value $=0.006)$ and Kendall test $(w=0.768 ; P$ value $=0.045)$. Results also indicated strong correlation between particulate matters especially PM 2.5 with the Covid-19 death cases (Spearman $r_{s}=0.654$ and $P$ value $<0.001 ;$ Kendall $w=0.832$, $P$ value $=0.022$ ). Thus it is clear that the particulate matters have major impact on Covid-19 pandemic in India and smaller the particle size higher is the risk factor.

\section{Declarations}

\section{Conflict of Interest Statement}

On behalf of all authors, the corresponding author states that there is no conflict of interest.

\section{Credit Author Statement}

Bibek Saha : Data Collection and processing

Animesh Debnath : Methodology, Data Analysis, Original draft preparation

Biswajit Saha : Conceptualization, Writing- Reviewing and Editing,

\section{References}

1. Bashir, M.F., Ma, B., Komal, B., Bashir, M.A., Tan, D., Bashir, M., 2020. Correlation between climate indicators and COVID-19 pandemic in New York, USA. Sci. Total Environ. 728, 138835.

2. Census report of Government of India. (http://censusindia.gov.in/Maps/Theme_based_Maps/Map_links/map2.aspx,)

3. Central Pollution Control Board (CPCB), Ministry of Environment, Forest and climate change, Govt. of India (13 https://app.cpcbccr.com/AQI_India/) 
4. Chen, D., Xiao, Y., Tang, S., 2019. Air quality index induced nonsmooth system for respiratory infection. Theor. Biol. 460, 160-169.

5. Chinazzi, M., Davis, J.T., Ajelli, M., Gioannini, C., Litvinova, M., Merler, S., y Piontti, A.P., Mu, K., Rossi, L., Sun, K., Viboud, C., 2020. The effect of travel restrictions on the spread of the 2019 novel coronavirus (COVID-19) outbreak.Science368 (6489), 395-400.

6. Conticini, E., Frediani, B., Caro, D., 2020. Can atmospheric pollution be considered a co-factor in extremely high level of SARS-CoV-2 lethality in Northern Italy? Environ. pollut. 261, 114465.

7. Croft, D.P., Zhang, W., Lin, S., Thurston, S.W., Hopke, P.K., Masiol, M., Squizzato, S., van Wijngaarden, E., Utell, M.J., Rich, D.Q., 2019. The association between respiratory infection and air pollution in the setting of air quality policy and economic change. Am. Thorac. Soc.16(3), 321-330.

8. de Souza, J.B., Reisen, V.A., Franco, G.C., Ispány, M., Bondon, P., Santos, J.M., 2018. Generalized additive models with principal component analysis: an application to time series of respiratory disease and air pollution data. J. R. Stat. Soc.: Series C (Appl. Stat.) 67(2), 453-480.

9. Fattorini, D., Regoli, F., 2020. Role of the chronic air pollution levels in the Covid-19 outbreak risk in Italy. Environ. Pollut. 264, 114732.

10. Frontera, A., Martin, C., Vlachos, K., Sgubin, G., 2020. Regional air pollution persistence links to covid19 infection zoning. J. Infect.DOI:https://doi.org/10.1016/j.jinf.2020.03.045.

11. Maier, B.F., Brockmann, D., 2020. Effective containment explains subexponential growth in recent confirmed COVID-19 cases in China. Science.DOI: 10.1126/science.abb4557.

12. Ministry of Health and Family welfare, Government of India (https://www.mohfw.gov.in/).

13. Qi, H., Xiao, S., Shi, R., Ward, M.P., Chen, Y., Tu, W., Su, Q., Wang, W., Wang, X., Zhang, Z., 2020. COVID19 transmission in Mainland China is associated with temperature and humidity: a time-series analysis. Total Environ. 728, 138778.

14. Rovira, J., Domingo, J.L., Schuhmacher, M., 2020. Air quality, health impacts and burden of disease due to air pollution (PM10, PM2. 5, NO2 and 03): Application of AirQ+ model to the Camp de Tarragona County (Catalonia, Spain). Sci. Total Environ. 703, 135538.

15. Shaddick, G., Thomas, M.L., Amini, H., Broday, D., Cohen, A., Frostad, J., Green, A., Gumy, S., Liu, Y., Martin, R.V., Pruss-Ustun, A., 2018. Data integration for the assessment of population exposure to ambient air pollution for global burden of disease assessment. Sci. Technol.52(16), 9069-9078.

16. Sharma, E., Deo, R.C., Prasad, R., Parisi, A.V., 2020. A hybrid air quality early-warning framework: An hourly forecasting model with online sequential extreme learning machines and empirical mode decomposition algorithms. Sci. Total Environ. 709, 135934.

17. Tosepu, R., Gunawan, J., Effendy, D.S., Lestari, H., Bahar, H., Asfian, P., 2020. Correlation between weather and Covid-19 pandemic in Jakarta, Indonesia. Total Environ. 725, 138436.

18. World bank Data (worldbank.org/indicator/EN.POP.DNST?locations=IN)

19. Wu, X., Nethery, R.C., Sabath, B.M., Braun, D., Dominici, F., 2020. Exposure to air pollution and COVID19 mortality in the United States. medRxiv. 
20. Yongjian, Z., Jingu, X., Fengming, H., Liqing, C., 2020. Association between short-term exposure to air pollution and COVID-19 infection: Evidence from China. Total Environ. 725, 138704.

\section{Figures}

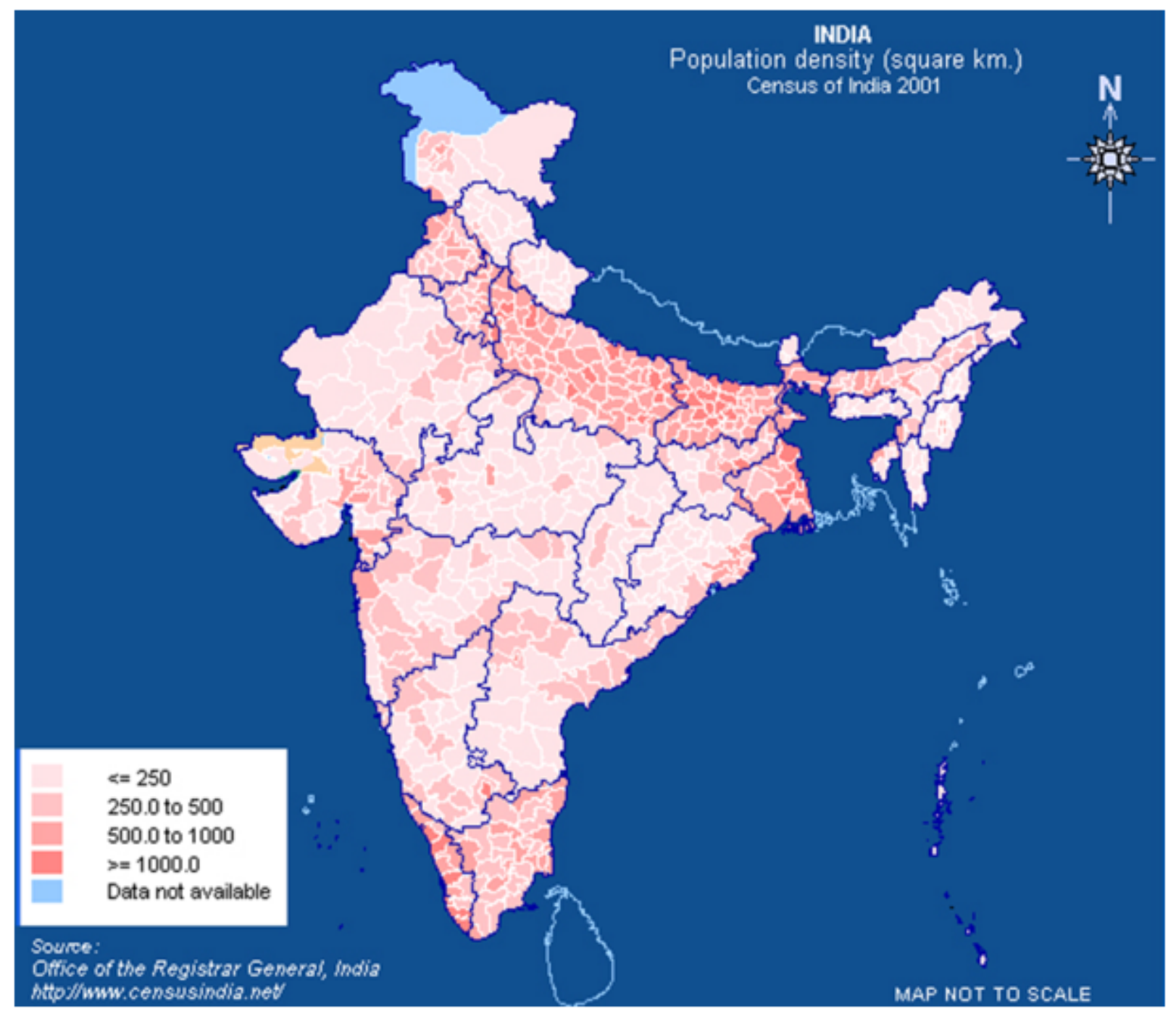

\section{Figure 1}

District wise population density distribution map of India. 


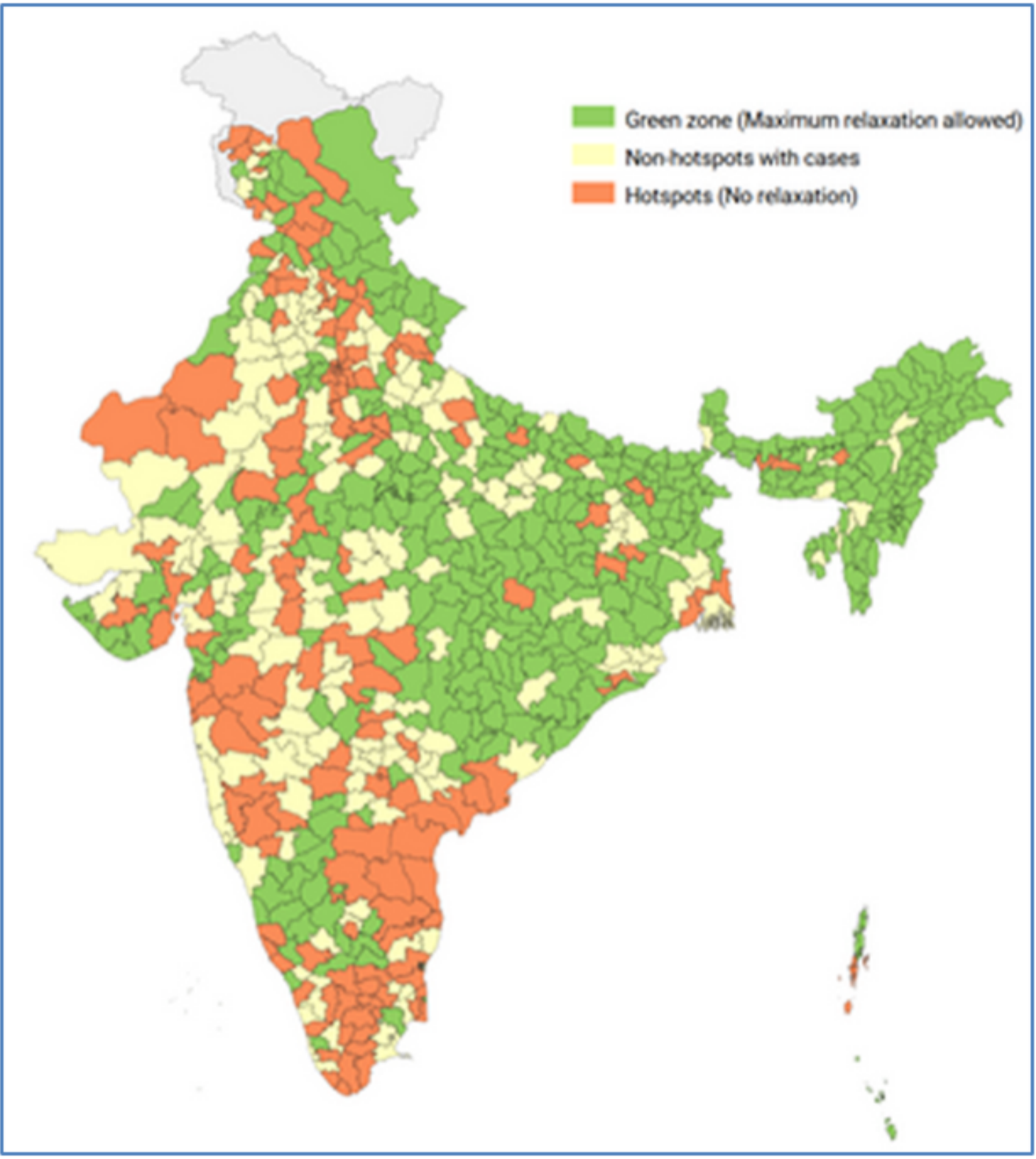

Figure 2

Red, orange and green zones of the India based on Covid-19 case distribution. 


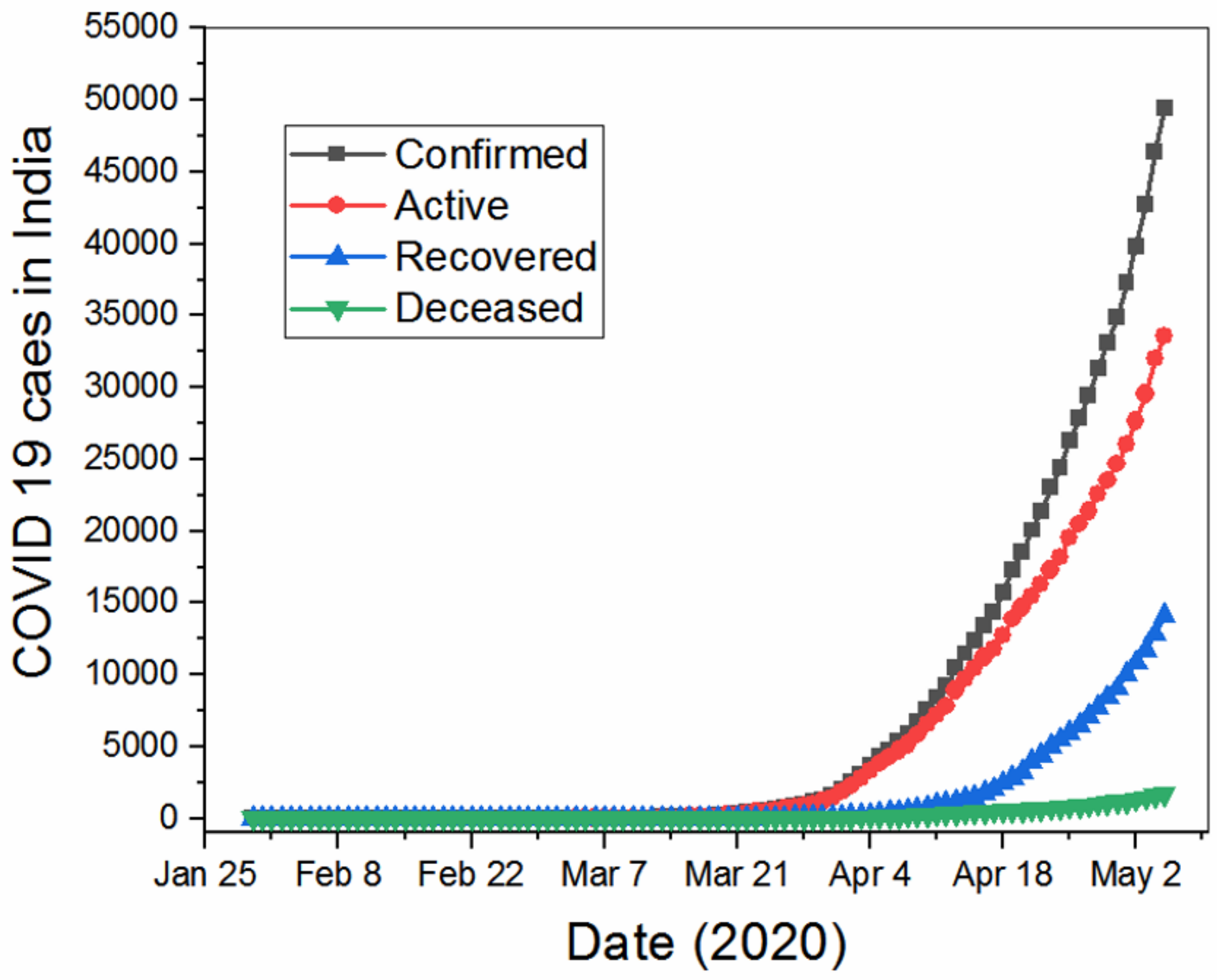

Figure 3

Details of Covid-19 cases in India as on 5th May 2020. 


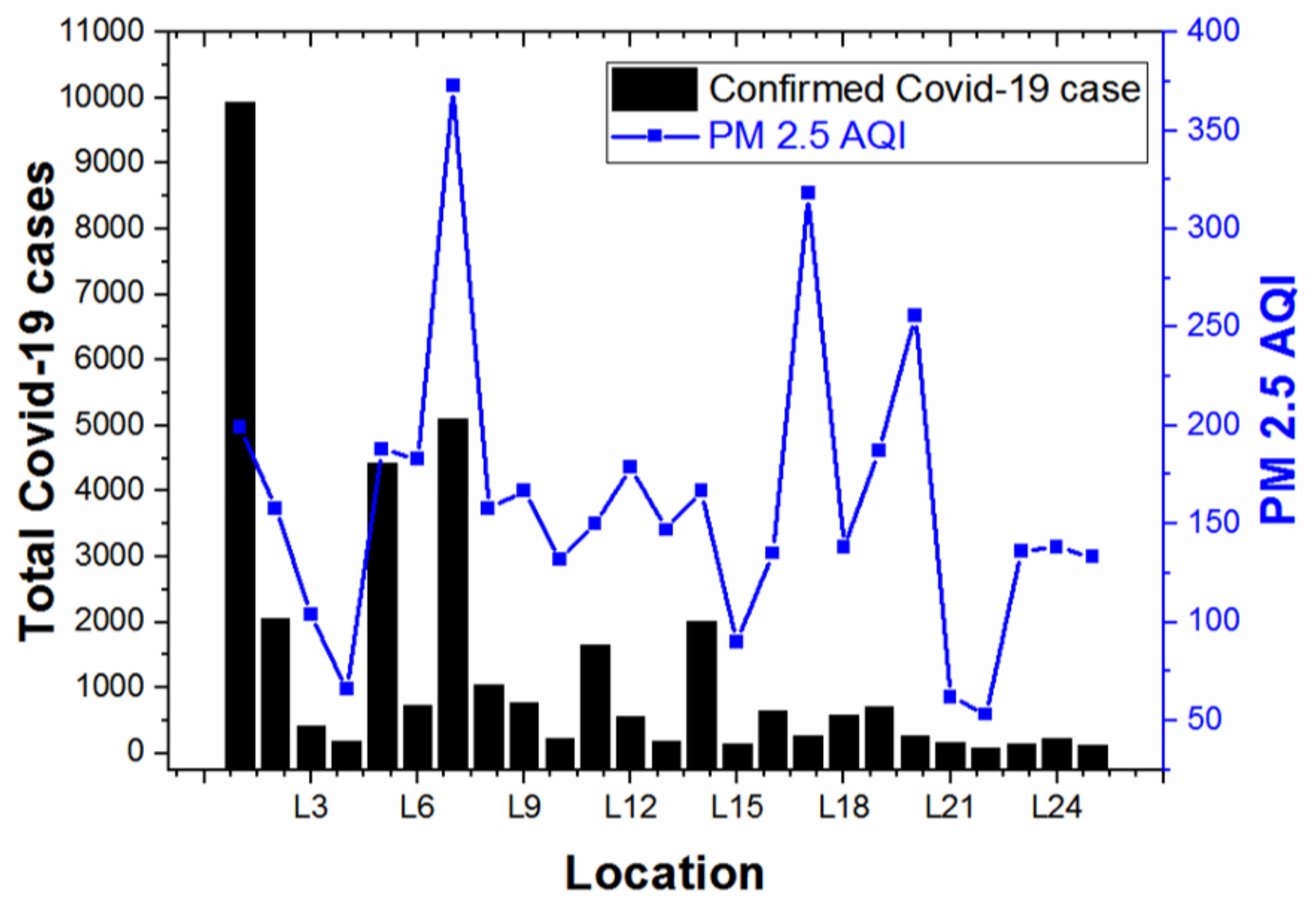

Figure 4

The variation of total Covid-19 cases with PM 2.5 AQI values in different cities of India. 


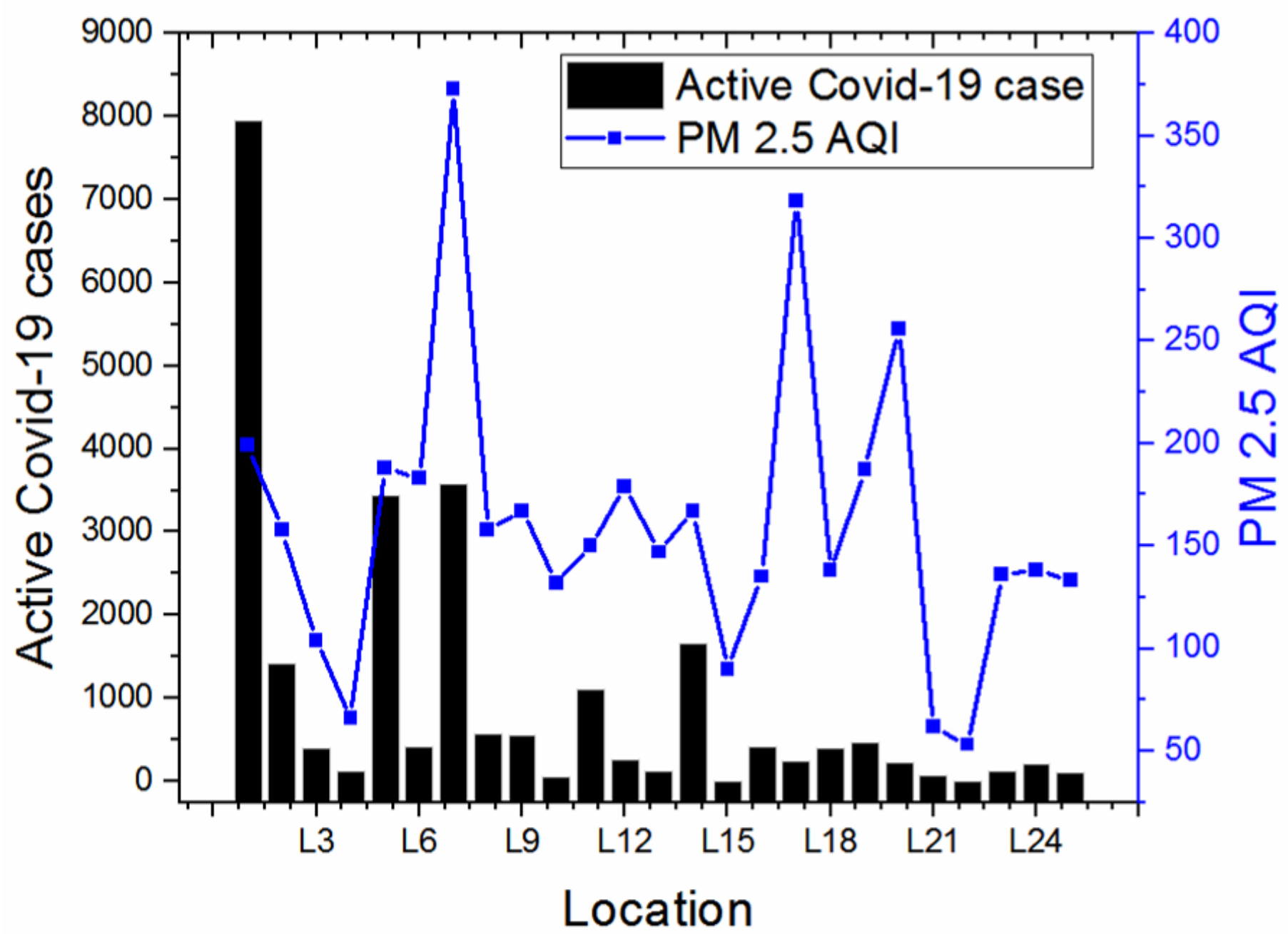

Figure 5

The variation of active Covid-19 cases with PM 2.5 AQI values in different cities of India. 


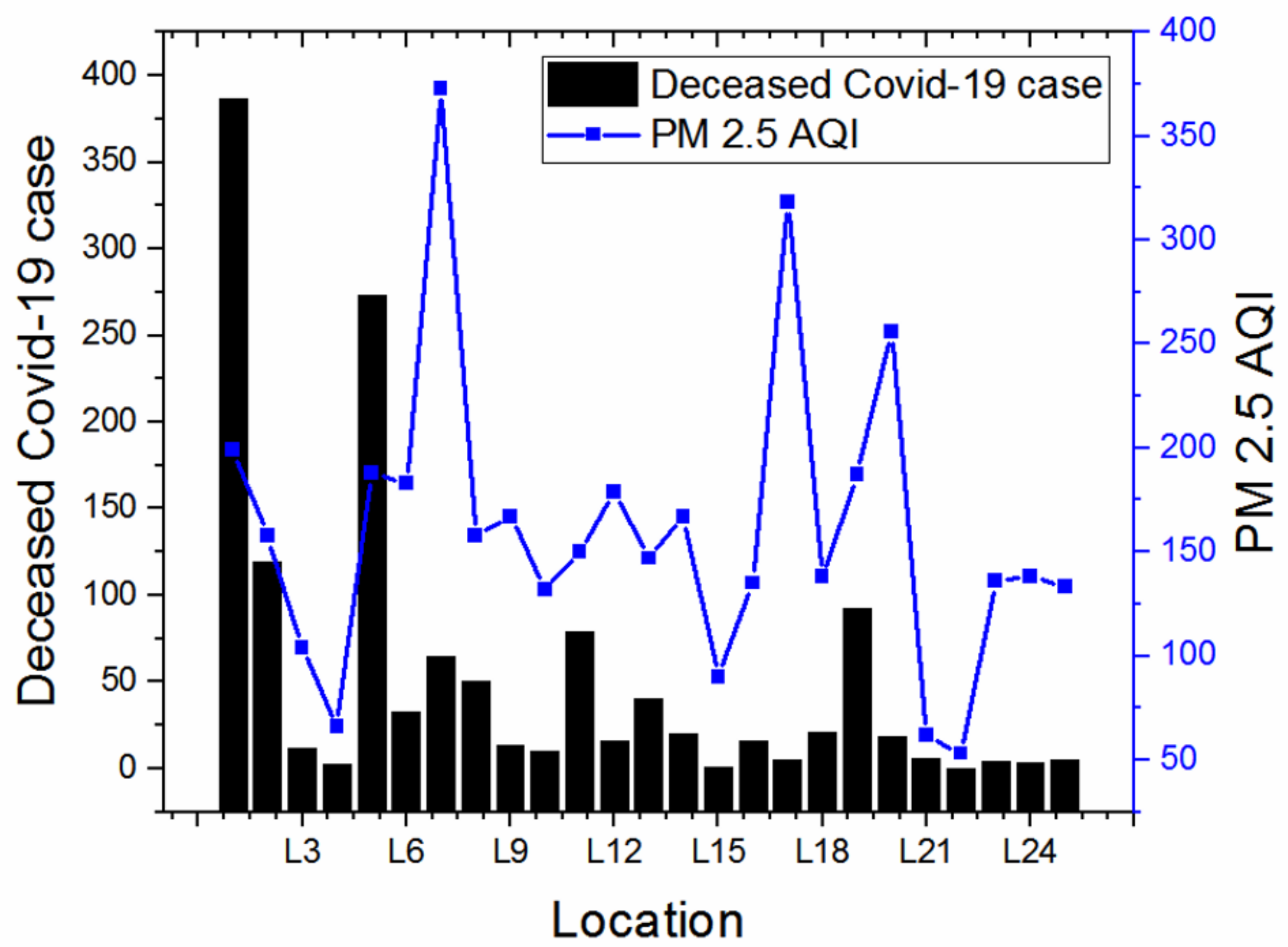

Figure 6

The variation of deceased Covid-19 cases with PM 2.5 AQI values in different cities of India. 


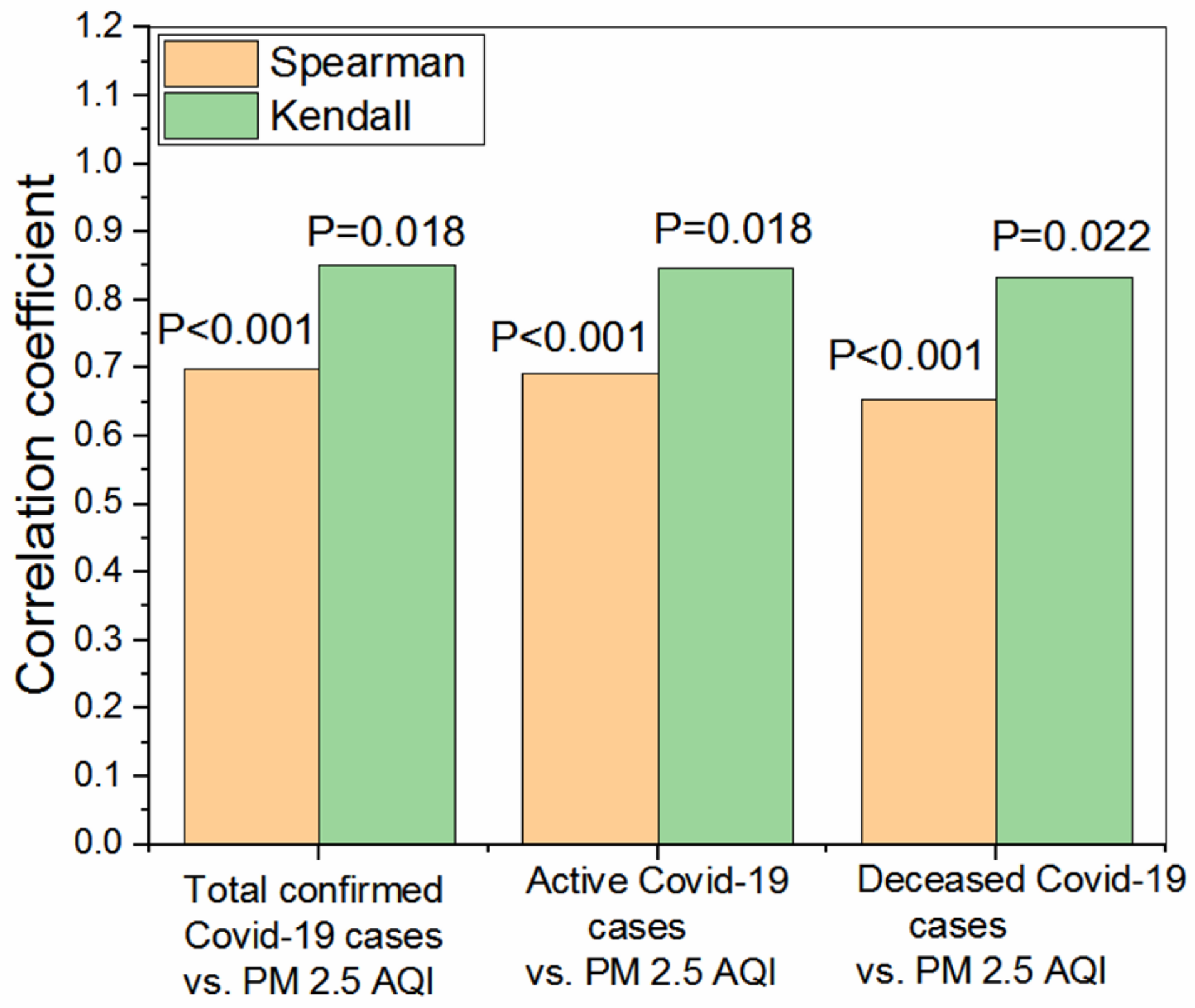

Figure 7

Highest Spearman and Kendall correlation coefficient between PM 2.5 AQI with Covid-19 parameters. 